\title{
TANGGUNG JAWAB HUKUM PERAWAT TERHADAP RAHASIA KESEHATAN PASIEN DI RSUD KOTA SEMARANG
}

\section{Nursing Law Responsibilities to Patient Health Secrets in Hospital City Semarang}

\author{
Wijanarko Heru Pramono \\ Akademi Keperawatan Widya Husada Semarang, Jl.Subali Raya no.12 Krapyak Semarang \\ e-mail: herupram423@gmail.com
}

\begin{abstract}
ABSTRAK
Semua informasi yang teridentifikasi mengenai status kesehatan pasien, kondisi medis, diagnosis, prognosis, dan tindakan medis dan semua informasi lain yang sifatnya pribadi, harus dijaga kerahasiaannya oleh seorang perawat, bahkan setelah kematian.Hasil penelitian menunjukkan, bahwa bentuk Tanggung Jawab Hukum Perawat Terhadap Wajib Simpan Rahasia Kesehatan Pasien, terdiri atas tanggung jawab administrasi yang berkaitan dengan izin sebagai perawat, tanggung jawab perdata yang berkaitan dengan wanprestasi maupun perbuatan melawan hukum, serta tanggung jawab pidana yang berkaitan dengan pelanggaran larangan yang memenuhi unsur tindak pidana.Faktoryang menjadi hambatan dan solusi tanggung jawab hukum perawat terhadap rahasia kesehatan pasien, berawal dari tindakan wanprestasi yang dilakukan oleh perawat.Hal itu terjadi karena perawat lalai dan tidak sengaja membocorkan rahasia kesehatan pasien serta perawat menganggap kondisi kesehatan pasien adalah hal biasa dan bukan rahasia.Akibat hukum bagi perawat yang lalai terhadap wajib simpan rahasia kesehatan pasienakan berorientasi pada hukum administratif, perdata dan pidana.
\end{abstract}

Kata Kunci :Tanggung Jawab Hukum, Rahasia Pasien

\begin{abstract}
All information identified regarding the patient's health status, medical condition, diagnosis, prognosis, and medical action and all other information of a personal nature, must be kept confidential by a nurse, even after death. The results of the study show that the form of the Nurse's Legal Responsibility for the Must Keep Patient's Health Secrets consists of administrative responsibilities relating to permission as a nurse, civil liability related to defaults and unlawful acts, and criminal liability related to violations of the prohibition which meets the element of criminal offense. Factors that become obstacles and nurses' legal responsibility solutions to the patient's health secrets, start from defaults carried out by nurses. This happened because the nurse was negligent and accidentally leaked the secrets of the patient's health and the nurse considered the patient's health condition to be normal and not confidential. The legal consequences for nurses who are negligent of the obligation to keep patient's health secrets will be oriented to administrative, civil and criminal law.
\end{abstract}

Keywords : Legal Responsibility, Patient Secrets

Vol. 1, No. 1, Juni $2018: 28-36$ 


\section{PENDAHULUAN}

Setiap Upaya Pembangunan Nasional harus dilandasi dengan wawasan kesehatan dalam arti pembangunan nasional harus memperhatikan kesehatan masyarakat dan merupakan tanggung jawab pihak baik pemerintah maupun masyarakat. Pelanggaran hukum dalam pelaksanaan pelayanan kesehatan apabila terjadi dapat diminta pertanggungjawaban hukum atau dengan kata lain dilakukan penegakan hukum.

Pemberian pelayanan kesehatan ini dilakukan secara adil dan merata, hal ini sesuai dengan tujuan utama dari pemerintah dalam Undang - Undang Dasar 1945 yakni menciptakan kesejahteraan yang adil dan makmur dengan melaksanakan pembangunan yang berkesinambungan, termasuk dalam pembangunan dibidang kesehatan. Pembangunan kesehatan bertujuan untuk meningkatkan kesadaran, kemauan dan kemampuan hidup sehat bagi setiap orang agar terwujud derajat kesehatan masyarakat yang setinggi - tingginya.Akses terhadap pelayanan kesehatan tidak boleh membeda - bedakan masyarakat atas tingkat sosial ekonominya. Penduduk yang tidak mampu atau miskin harus mempunyai kesempatan yang sama dengan penduduk yang mampu dalam mengakses pelayanan kesehatan yang berkualitas.

Masyarakat Indonesia pada umumnya belum terbiasa secara aktif mendapatkan informasi dalam penggunaan layanan medis. Pasien sebagian menyerahkan sepenuhnya kepada dokter atau perawat mengenai pelayanan medis yang akan diterima oleh dirinya. Pasien yang menggunakan pelayanan medis belum banyak yang mengetahui bahwa mereka mempunyai hak dan kewajiban.

Pasien merupakan orang yang memerlukan pertolongan tenaga kesehatan karena penyakitnya, sedangkan tenaga kesehatan adalah orang yang dimintai pertolongan karena kemampuan profesinya yang dianggap mampu mengobati penyakit.Hubungan tenaga kesehatan dan pasien terjadi pada saat tenaga kesehatan dalam hal ini dokter atau perawat bersedia menerima klien sebagai pasiennya. Dengan demikian dokter atau perawat berada di posisi paling kuat dan diharapkan akan bersikap bijaksana dan tidak memanfaatkan kelemahan pasien. Sehingga dokter atau perawat mempunyai kewajiban moral untuk menghormati hak pasiennya sebagai manusia.

Menurut pasal 45 Undang - Undang Nomor 29 Tahun 2004 tentang Praktek Kedokteran, perikatan yang terjadi diantara tenaga kesehatan dengan pasien merupakan suatu bentuk persetujuan dari pasien sebelum tenaga kesehatan melakukan tindakan medis kepada pasien. Tindakan medis tersebut yang mengandung resiko yang tinggi harus diberikan dengan persetujuan tertulis yang ditandatangani oleh yang berhak memberikan persetujuan. Adanya suatu perikatan, diharapkan pasien atau keluarga pasienpun dapat lebih mengerti pada resiko yang akan terjadi.

Kesehatan sebagai hak asasi manusia harus diwujudkan dalam bentuk pemberian berbagai upaya kesehatan kepada seluruh mesayarakat melalui penyelenggaraan pembangunan kesehatan yang berkualitas 
dan terjangkau oleh masayarakat.Pembangunan kesehatan ditujukan untuk meningkatkan kesadaran, kemauan dan kemampuan hidup sehat bagi setiaporang dalam rangka mewujudkan derajat kesehatan yang optimal sebagai salah satu unsur kesejahteraan sebagaimana dimaksud dalam pembukaan Undang Undang Dasar Tahun 1945.

Tenaga kesehatan adalah setiap orang yang mengabdikan diri dalam bidang kesehatan serta memiliki pengetahuan dan atau ketrampilan melalui pendidikan dibidang kesehatan dan untuk jenis tertentu memerlukan kewenangan untuk melakukan upaya kesehatan. Berdasarkan definisi tersebut maka tenaga kesehatan berwenang untuk menyelenggarakan pelayanan kesehatan sesuai bidang keahliannya, namun dalam penyelenggaraannya, setiap tenaga kesehatan wajib memiliki izin dari pemerintah, sehingga masyarakat sebagai pengguna jasa akan mendapatkan pelayanan yang aman, terjamin serta masyarakat maupun tenaga kesehatan sendiri juga terlindungi dari hokum.

Perawatan merupakan salah satu profesi tenaga kesehatan yang memberikan pelayanan kesehatan langsung baik kepada individu, keluarga dan masyarakat.Sebagai salah satu tenaga profesional, keperawatan menjalankan dan melaksanakan kegiatan praktek keperawatan dengan mengunakan ilmu pengetahuan dan teori keperawatan yang dapat dipertanggung jawabkan, dimana ciri sebagai profesi adalah mempunyai body of knowledge yang dapat diuji kebenarannya serta ilmunya dapat diimplementasikan kepada masyarakat langsung.
Pelayanan kesehatan dan keperawatan yang dimaksud adalah bentuk implementasi praktek keperawatan yang ditujukan kepada pasien/klien baik kepada individu, keluarga dan masyarakat dengan tujuan upaya peningkatan kesehatan dan kesejahteraan guna mempertahankan dan memelihara kesehatan serta menyembuhkan dari sakit, dengan kata lain upaya praktek keperawatan berupa promotif, preventif, kuratif dan rehabilitasi.

Dalam melakukan praktek keperawatan, perawat secara langsung berhubungan dan berinteraksi kepada penerima jasa pelayanan, dan pada saat interaksi inilah sering timbul beberapa hal yang tidak diinginkan baik disengaja maupun tidak disengaja, kondisi demikian inilah sering menimbulkan konflik baik pada diri pelaku dan penerima praktek keperawatan.Oleh karena itu profesi keperawatan harus mempunyai standar profesi dan aturan lainnya yang didasari oleh ilmu pengetahuan yang dimilikinya, guna memberi perlindungan kepada masyarakat. Dengan adanya standar praktek profesi keperawatan inilah dapat dilihat apakah seorang perawat melakukan malpraktek, kelalaian ataupun bentuk pelanggaran praktek keperawatan lainnya.

Terjadinya kelalaian seorang perawat dalam menjaga rahasia kondisi kesehatan pasien juga sebenarnya termasuk dalam pelanggaran hukum.Hal ini sebenarnya juga harus menjadi perhatian seorang perawat dalam menjalankan implementasi keperawatan. Sebagai contoh pernah terjadi bahwa seorang perawat bernama Budi kurang lebih pada bulan Oktober tahun 2013 
merawat seorang pasien yang bernama $\mathrm{Nn}$. F Usia 32 tahun. Saat itu Nn. F di rawat disalah satu Rumah Sakit di Jawa Tengah dengan diagnosa medis Ca Mamae (kanker payudara). Nn. F mengikuti proses terapi dan dari Rumah Sakit tersebut mengharuskan untuk segera dilakukan tindakan operasi. Meskipun Nn. F dioperasi tetapi sakit yang diderita Nn. F tidak kunjung sembuh.Beberapa bulan kemudian ada seorang pria datang yang mengaku sebagai keluarga korban dan menanyakan kondisi kesehatan Nn. F, dikarenakan pria tersebut merasa bahwa Nn. F tidak sembuh sembuh setelah sekian lama opname di Rumah Sakit sampai pada akhirnya di operasi. Seorang perawat menjelaskan kondisi kesehatan Nn. F kepada pria tersebut, padahal tidak lain pria tersebut adalah calon suami Nn. F. Atas kelalaian yang sudah dilakukan oleh perawat atas disampaikannya tentang rahasia kondisi kesehatan Nn. F kepada pria tersebut, akhirnya pria tersebut tidak jadi menikahi Nn. F dikarenakan tahu bahwa Nn. F menderita $\mathrm{Ca}$ Mamae. Dalam kejadian tersebut perawat secara jelas sudah melanggar kode etik dan aturan perundang undangan dikarenakan sudah membocorkan rahasia kondisi kesehatan pasien.

Berkaitan dengan uraian tersebut diatas maka perlu dilakukan penelitian tentang tanggung jawab hukum perawat terhadap rahasia kesehatan pasiendi RSUD kota semarang.

\section{HASIL DAN SARAN}

Berkaitan dengan fungsi perawat, maka perawat mempunyai kemampuan bertanggung jawab dalam menjalankan fungsi yang mandiri dalam asuhan keperawatan, sementara dalam fungsi kolaborasi beertanggung jawab berada pada ketua tim kesehatan dan dalam fungsi dependen tanggung jawab berada pada dokter yang berwenang melakukan tindakan medis tertentu kepada pasien.

Tabel 1.

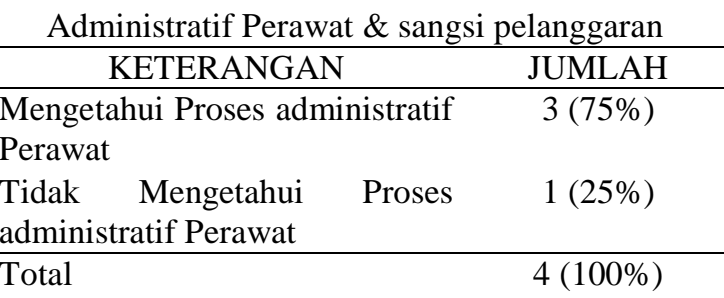

Berdasarkan Tabel tersebut dapat diketahui, bahwa dari tiga $(75 \%)$ informan tersebut telah mengetahui proses administratif sebagai tenaga kesehatan dalam hal ini adalah Perawat. Dari ketiga informan tersebut menjelaskan secara detail proses administratif secara hukum sebagai seorang perawat. Kemudian dari satu $(25 \%)$ informan tidak mengetahui proses administratif seorang perawat.

Dari hasil studi di kota Semarang ini dapat disimpulkan, bahwa proses administratif sebagai Perawat diketahui dan dipahami oleh sebagian besar informan. Artinya, bahwa sebenarnya aturan hukum secara administratif khususnya pada profesi keperawatan sudah sebagaian besar dipahami dari tenaga kesehatan perawat itu sendiri ataupun dari pihak terkait. 
Tabel. 2

Pengetahuan Tentang isi UU Nomor 38 tahun 2014 Pasal 38 Tentang Keperawatan ayat (e) dan Tentang Isi PERMENKES No.269/MENKES/PER/III/2008 Pasal 10

\begin{tabular}{lcc}
\hline PENGETAHUAN & TAHU & TIDAK TAHU \\
\hline Undang-Undang & & \\
No 38 Tahun 2014 & $0(0 \%)$ & $4(100 \%)$ \\
Psl 38 ayat (e) & & \\
PERMENKES & & \\
No.269/MENKES/ & $0(0 \%)$ & $4(100 \%)$ \\
PER/III/2008 Psl 10 & &
\end{tabular}

Berdasarkan Tabel 4.2 dapat diketahui, bahwa dari empat informan yang di wawancarai, tidak satupun yang mengetahui tentang isi UU Nomor 38 tahun 2014 Pasal 38 Tentang Keperawatan ayat (e) dan isi PERMENKES No.269/MENKES/PER/III/2008 Pasal 10 Tentang Rekam Medis.

Hasil Wawancara :

Setelah dijelaskan tentang isi dan makna UU Nomor 38 tahun 2014 Pasal 38 Tentang Keperawatan ayat (e) dan isi PERMENKES No.269 MENKES/PER/III/2008 Pasal 10 Tentang Rekam Medis, pada umumnya semua informan menyatakan bahwa, tanpa harus mengenal isi dan makna undang-undang dan Permenkes yang telah disebutkan, semua informan menyadari bahwa isi dari undangundang dan permenkes tersebut memang sudah dilaksanakan, meskipun dari isi undang-undang dan permenkes tersebut dalam keseharianya ada yang mungkin tidak sengaja di langgar oleh petugas kesehatan secara umum dan oleh perawat pada khususnya.

Tiga orang informan mengungkapkan, bahwa mengenal tentang undang-undang
Keperawatan dan peraturan tentang rekam medis, tetapi secara detail tidak tahu isi dari undang-undang dan permenkes tersebut meskipun sebenarnya informan tersebut sadar bahwa dirinya telah melasanakan isi dari perundang-undangan tersebut meskipun bahwa ada atau mungkin terkadang melanggar aturan tersebut tanpa disadarinya.

Satu orang informan mengungkapkan hal yang senada, bahwa sebenarnya informan tersebut yakin ada peraturan perundangan yang mengatur tentang bagaimana seorang tenaga kesehatan menjalankan tugas dan tanggung jawabnya sesuai dengan ketentuan-ketentuan yang berlaku, meskipun informan tersebut tida mengetahui secara pasti perundangundangan yang mana yang mengatur hal tersebut.

Dari hasil studi di kota Semarang ini dapat disimpulkan, bahwa meskipun tenaga kesehatan umumnya dan perawat pada khususnya tidak mengenal isi dari undangundang Nomor 38 tahun 2014 Pasal 38 Tentang Keperawatan ayat (e) dan isi PERMENKES

No.269/MENKES/PER/III/2008 Pasal 10 Tentang Rekam Medis, namun mereka memiliki tanggung jawab hukum ditinjau dari aspek hukum perdata, karena mereka mau melaksanakan isi dan perintah dari undang-undang dan permenkes tersebut. 
Tabel.2

Pengetahuan Tentang Sangsi Administratif, Sangsi Perdata dan Sangsi Pidana atas pelanggaran wajib simpan rahasi pasien

\begin{tabular}{ccc}
\hline PENGETAHUAN & TAHU & $\begin{array}{c}\text { TDK } \\
\text { TAHU }\end{array}$ \\
\hline Sangsi Administratif & & \\
Pelanggaran Wajib & 4 & $0(0 \%)$ \\
Simpan Rahasia & $(100 \%)$ & \\
Kesehatan Pasien & & \\
Sangsi Perdata & & \\
Pelanggaran Wajib & 2 & $2(50 \%)$ \\
Simpan Rahasia & $(50 \%)$ & \\
Kesehatan Pasien & & \\
$\quad$ Sangsi Pidana & 2 & $2(50 \%)$ \\
Pelanggaran Wajib & $(50 \%)$ & \\
Simpan Rahasia Pasien & & \\
\hline
\end{tabular}

Berdasarkan Tabel. 2 dapat diketahui, bahwa dari empat informan yang di wawancarai, semuanya mengetahui tentang apa sangsi administratif bagi petugas perawat, dalam hal pelanggaran terhadap wajib simpan rahasia kesehatan pasien.

Kemudian terkait dengan sangsi perdata pelanggaran terhadap wajib simpan rahasia kesehatan pasien, dua informan menyatakan tidak tahu dan 2 informan menyatakan tahu tentang bagaimana sangsi perdata terhadap pelanggaran wajib simpan rahasia kesehatan pasien.

Pada Sangsi pidana, dua informan menyatakan tidak tahu dan 2 informan menyatakan tahu tentang bagaimana sangsi pidana terhadap pelanggaran wajib simpan rahasia kesehatan pasien.

Hasil Wawancara :

Setelah dijelaskan tentang sangsi administratif, sangsi perdata dan sangsi pidana terhadap pelanggaran wajib simpan rahasia kesehatan pasien, tanpa harus mengetahui secara detai dari sangsi tersebut tetapi, semua informan menyadari bahwa apa yang dikerjakan dalam rangka proses terapeutik sudah sesuai dengan kaidah dari sangsi-sangsi tersebut, meskipun dari sangsi-sangsi tersebut dalam keseharianya ada yang mungkin tidak sengaja di langgar oleh petugas kesehatan secara umum dan oleh perawat pada khususnya.

Dari hasil studi di kota Semarang ini dapat disimpulkan, bahwa meskipun tenaga kesehatan umumnya dan perawat pada khususnya tidak mengenal isi dari undangundang Nomor 38 tahun 2014 Pasal 38 Tentang Keperawatan ayat (e) dan isi dari PERMENKES Nomor 269/MENKES/PER/III/2008 Pasal 10 Tentang Rekam Medis, namun mereka memiliki tanggung jawab hukum ditinjau dari aspek hukum perdata, karena mereka mau melaksanakan isi dan perintah dari undang-undang dan permenkes tersebut.

Tabel.3

Alasan Terjadi Pelanggaran

Terhadap Wajib Simpan Rahasia Kesehatan Pasien

\begin{tabular}{|c|c|}
\hline Alasan Terjadi Pelanggaran & Informan \\
\hline $\begin{array}{c}\text { Perawat tidak sengaja } \\
\text { membicarakan rahasia } \\
\text { kesehatan pasien kepada } \\
\text { perawat atau tenaga medis lain } \\
\text { yang bukan sebagai pemangku } \\
\text { kepentingan pasien }\end{array}$ & $3(75 \%)$ \\
\hline $\begin{array}{l}\text { Perawat tidak mengetahui hal } \\
\text { apa saja yang membolehkan } \\
\text { seorang perawat membuka } \\
\text { rahasia kesehatan pasien }\end{array}$ & $2(50 \%)$ \\
\hline $\begin{array}{l}\text { Perawat menganggap kondisi } \\
\text { kesehatan pasien adalah hal } \\
\text { yang biasa }\end{array}$ & $2(50 \%)$ \\
\hline
\end{tabular}

Berdasarkan Tabel.3 tersebut dapat diketahui bahwa alasan Terjadinya Pelanggaran Terhadap Wajib Simpan 
Rahasia Kesehatan Pasien pada umumnya karena :

Perawat tidak sengaja membicarakan rahasia kesehatan pasien kepada perawat atau tenaga medis lain yang bukan sebagai pemangku kepentingan pasien

Hasil wawancara :

Tiga orang informan mengungkapkan, bahwa ketika membicarakan rahasia kesehatan pasien kepada perawat yang lain hal tersebut dianggap bahwa itu bukanlah suatu pelanggaran.

Seorang informan menggungkapkan, bahwa membicarakan rahasia kesehatan pasien kepada perawat atau tenaga medis lain yang bukan sebagai pemangku kepentingan pasien merupakan hal yang sudah melanggar kode etik keperawatan.

Perawat tidak mengetahui hal apa saja yang membolehkan seorang perawat membuka rahasia kesehatan pasien.

Hasil wawancara :

Dua orang informan mengungkapkan, hal yang diperbolehkan seorang perawat membuka rahasia kesehatan pasien adalah ketika mendapatkan ijin dari pasien tersebut, untuk kepentingan kesembuhan pasien, untuk diungkap dalam sebuah kasus hukum dan untuk keperluan kependingan pendidikan.

Dua orang informan mengungkapkan, tidak mengetahui secara detail tentang apa saja hal yang diperbolehkan seorang perawat untuk membuka rahasia kesehatan pasien Perawat menganggap kondisi kesehatan pasien adalah hal yang biasa Hasil wawancara :

Vol. 1, No. 1, Juni $2018: 28-36$
Dua orang informan mengungkapkan, bahwa kesehatan pasien adalah hal yang biasa Dua orang informan mengungkapkan, bahwa kesehatan pasien adalah hal yang benar-benar harus dijaga kerahasiaannya, dan tentunya merupakan tanggung jawab perawat dan tenaga medis yang lain yang pada saat itu mengetahui kondisi kesehatan pasien.

Dengan demikian dapat disimpulkan, bahwa pada umumnya Alasan Terjadi Pelanggaran Terhadap Wajib Simpan Rahasia Kesehatan Pasien : Pertama, Perawat tidak sengaja membicarakan rahasia kesehatan pasien kepada perawat atau tenaga medis lain yang bukan sebagai pemangku kepentingan pasien, Kedua, Perawat tidak mengetahui hal apa saja yang membolehkan seorang perawat membuka rahasia kesehatan pasien dan ketiga Perawat menganggap kondisi kesehatan pasien adalah hal yang biasa.

\section{KESIMPULAN}

Berdasarkan hasil penelitian dapat disimpulkan, bahwa :

Tanggung Jawab Hukum Perawat Terhadap Rahasia Kesehatan Pasien, terdiri atas tanggung jawab administrasi yang berkaitan dengan izin sebagai perawat, tanggung jawab perdata yang berkaitan dengan wanprestasi maupun perbuatan melawan hukum, serta tanggung jawab pidana yang berkaitan dengan pelanggaran larangan yang memenuhi unsur tindak pidana. Faktor-faktor yang menjadi hambatan dan solusi tanggung jawab hukum perawat terhadap wajib simpan rahasia kesehatan pasien, pada umumnya bermuara dari tindakan wanprestasi yang dilakukan 
oleh perawat.Hal itu dapat terjadi karena perawat lalai karena secara tidak sengaja telah membocorkan rahasia kesehatan pasien dan perawat menganggap bahwa kondisi kesehatan pasien adalah hal biasa dan bukan rahasia.

Akibat hukum bagi perawat yang lalai terhadap wajib simpan rahasia kesehatan pasien akan berorientasi pada hukum administratif, hukum perdata dan hukum pidana. Hal ini tergantung bagaimanakah rahasia kondisi kesehatan pasien sampai di ketahui oleh orang lain yang bukan pemangku kepentingan, termasuk dari keluarga pasien yang mana kondisi kesehatan pasien adalah hak mutla pasien terkecuali pasien memberikan ijin untuk diberitahukan kepada pihak keluarga pasien.

\section{SARAN}

Kebutuhan masyarakat sebagai pasien, seharusnya perawat mengetahui dari apa yang menjadi batasan-batasan dalam pengelolaan Asuhan Keperawatan. Selain itu, perawat dituntut untuk sadar hukum, sehingga perawat mengetahui secara hukum mana yang menjadi hak dan mana yang menjadi kewaiban perawat. Selain berkaitan dengan hukum, keperawatan mempunyai lima kode etik yang seharusnya perawat mengetahui dan mentaati kode etik tersebut, sehingga tidak ada pelanggaran dalam menjalankan tugas sebagai perawat khususnya dalam menjaga rahasia kondisi kesehatan pasien.

\section{DAFTAR PUSTAKA}

A.A. Gde Muninjaya. 2004. Manajernen Kesehatan. Penerbit Buku Kedokteran EGG, Jakarta

Abdukadir Muhammad 2004. "Hukum dan Penelilian Hukum" , Citra Aditya Bakti, Bandung

Aman Santoso, 2003.Metode Penelitian Hukum Normatif dan Sosiologis dengan Analisa Kualitatif, FH UNTAG, Semarang

Asmadi, 2008.Konsep Dasar Keperawatan. EGC Jakarta

Djojodirdjo Moegni, 1979. Perbuatan Melawan Hukum : Tanggung Gugat untuk kerugian, yang disebabkan karena perbuatan melawan hukum, Pradnya Paramita, Jakarta

Guwandi, 2004.Hukum Medical, Fakultas Kedokteran Universitas Indonesia, Jakarta

Hendri, 2014.Etika \& Hukum Kesehatan, Buku Kedokteran, EGC, Jakarta

Komariah, 2001.Hukum Perdata, Edisi Revisi, Universitas Muhammadiyah Malang, Malang

Kusnanto, 2003.Profesi dan Praktik Keperawatan Profesional, EGC, Jakarta

Nursalam, 2007.Manajeman Keperawatan Aplikasi Dalam Praktik Keperawatan Profesional, Salemba Medika, Jakarta Nursalam, 2008.Proses dan Dokumentasi Keperawatan (ed 2), Salemba Medika, Jakarta

Nusye KI Jayanti, 2009. Penyelesaian Hukum Dalam Malpraktek Kedokteran, Pustaka Yustisia, Yogyakarta 
Praptiningsih Sri, 2007.Kedudukan Hukurn Perawat Dalam UpayaPelayanan Kesehatan di Rumah Sakit, PT. Raja Grafindo Persada, Jakarta

Prawirohardjo, Sarwono, 2002. Ilmu Kebidanan, Yayasan Bina Pustaka Sarwono Prawirodardjo, Jakarta

Soerjono Soekanto, 1993. Mengenal Sosiologi Hukum, cetakan ke VI, Rajawali Pers, Jakarta

Sri Wedati, 2003. Pengantar Manajemen Keperawatan, MMR UGM, Yogyakarta
Sunaryo, 2004.Psikologi Untuk Keperawatan, Buku Kedokteran EGG, Jakarta

Suwignyo G., 2007. Manajemen Kinerja Pelayanan Rumah Sakit, Sagung Seto, Jakarta

Widiyono 2004, Wewenang Dan Tanggung Jawab, Ghalia Indonesia, Bogor 